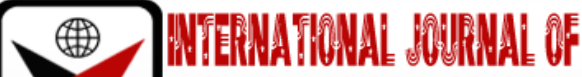

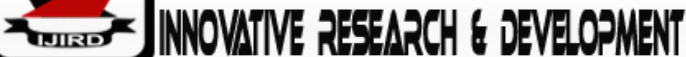

ISSN 2278 - 0211 (Online)

\section{Employees' Attitude and Implementation of Performance Appraisal System in the Ministry of Education in Nairobi City County, Kenya}

\begin{tabular}{c}
\hline Hellen Chebet Boruett \\
Student, Department of Curriculum Instruction and Education Management, \\
Masaai Mara University, Narok, Kenya \\
Dr. Florence Kisirikoi \\
Senior Lecturer, Department of Curriculum Instruction and Education Management, \\
School of Education, Masaai Mara University, Narok, Kenya \\
Dr. Magdalene Dimba \\
Dean, School of Humanities and Social Sciences, Strathmore University, Nairobi, Kenya \\
Dr. Alexander Ronoh \\
Senior Lecturer, Department of Curriculum Instruction and Education Management, \\
School of Education, Masaai Mara University, Narok, Kenya
\end{tabular}

\begin{abstract}
:
Performance appraisal (PA) is a critical element in the performance management system and a key human resource management function which is used to track individual contribution and work performance against organizational goals and to identify individual strengths and opportunities for future improvements. However, in the Ministry of education, performance appraisal seems not to be effective mainly due to the perceptions the employees hold towards the implementation of performance appraisal that it is a bureaucratic process, with little relevance on improving performance and accountability, which consequently led to the less importance and emphasis attached to it. This study determined the effects of employee attitude on the implementation of performance appraisal system among the employees in the Ministry of Education in Nairobi City County, State Department of Early Learning and Basic Education. The study adopted the concurrent mixed methods design where quantitative and qualitative methodologies were employed, simultaneously. The researcher used stratified sampling method to select the samples of the study by stratifying the staff into Education officers and Quality Assurance and Standards officers (QASOs). Semi-structured questionnaires and interview guides were used to collect data from the respondents. The study recommends that "Appraisal training by MoE"; and "Perceived organization support by MoE"; are the main critical factors that need to be seriously addressed to improve employees' Attitude on the implementation of Performance Appraisal System. The anticipated key beneficiaries of the findings include human resources department of the Ministry of Education, the Public service management, other institutions and future researchers.
\end{abstract}

Keywords: Implementation of Performance Appraisal System (PAS), organization support \& appraisal training, employee attitude

\section{Introduction}

Performance appraisal (PA) is a critical element in the performance management system and a key human resource management function. It is a vital tool to measure the work set by any organization to its employees. Rao (2005) advocates that performance appraisal is a method of evaluating the behaviour of employees in the work spot, normally including both the quantitative and qualitative aspects of job performance. Performance Appraisal (PA) forms the core of performance management systems. According to Swanepoelet al. (2000) Performance Appraisal is a formal and systematic process of identifying, observing, measuring, recording and developing the job-relevant strengths and weaknesses of employees. Fletcher (2004) submits that the PA has a strategic approach and integrates organizational policies and human resource activities. Performance Appraisal should also be viewed as a system of highly interactive processes which involve personnel at all levels in differing degrees in determining job expectations, writing job descriptions, selecting relevant appraisal criteria, developing assessment tools and procedures, and collecting, interpreting, and reporting results (Saari, \&Judge, 2004).

Some form of appraisal has existed since organizations emerged and has been the basis of selection of staff for promotion, increased reward or dismissal (Bratton \& Gold, 2003). Merit rating was used for the first time during the 
Second World War as a method of justifying an employee's pay (Griffin \& Moorhead, 2014). The process was based on material outcomes where higher output was rewarded with higher pay and vice-versa.

Globally, conducting employee performance appraisals has been very challenging for both the managers and employees (Brewster \&Suutari, 2005). Looking at the difference between Chinese and Western employee performance appraisals, Shen (2004) found out that the Chinese appraisals are less transparent than the Western appraisals. The Chinese companies also do not provide training in order to improve appraisal skills and the appraisals are usually limited in feedback and communication (Shen, 2004). The organizational climate must be cooperative rather than competitive Johns, (2010), Bowling, Beehr, Wagner \&Libkuman, (2005. Such impediments can complicate the process making it difficult to obtain true and fair feedback of the employee's performance, which can affect the attitudes and approach the raters will have towards the process which has been shown to affect the quality of the appraisals. Lack of proper training and feedback management is not only critical in influencing the attitude of the ratees' but also the raters towards the PAS, Brown et al, (2010). They may view the PAS as effort in futility.

In Kenya, the performance appraisal system in use in the Civil Service was introduced in 2006 as a Government initiative. The aim of which was to enhance efficiency and effectiveness in public service delivery through review of systems, processes and structures in the government ministries and departments Guidelines on Deepening Rationalization, (2002). Kenya's Rapid Results Initiative (RRI) targets greater alignment of existing performance management tools GOK, (2008). It focuses on operational performance management, monitoring and reporting tools and instruments. This requires proper alignment of leadership competencies and a performance appraisal system, which deliver accurate results. Evaluation is not only a matter of using the right form or method, but it's rather dependent on the openness and willingness of the parties to do it rightly (Segalla\&DeNisi, 2014).

The Ministry of Education of the Kenya Government, observed that employees view performance appraisal as a routine exercise without any impact GOK, (2012). It would be inappropriate for organizations to emphasize more on training without paying special attention to performance appraisal as Rao (2005) acknowledges that it is the outcome of performance appraisal that would reveal training needs. Understanding the effect of the employee attitude towards PAS is important in establishing an effective system.

In order to develop an effective PAS, the individuals who are involved as raters should undergo training (Ochot, Maronga, Muathe, Nyabwanga\&Ronoh,2012). Although they should be trained on the process of managing, motivating and evaluating employee performance, the PAS should not be seen as a simple "quick fix" solution. This can create a negative attitude and lack of support among the employees towards the PAS while it should be viewed within its wider context of performance management Peter, Mulvihill, Rebecca \& Freddy (2017). All employees involved in the performance rating process must be involved throughout the process. According to Bertoneet al (1998), involving employees will make them understand organizational goals, what is expected of them and what they will expect for achieving their performance goals. This study endeavours to find out the effect of the employees' attitude on appraisal training on the implementation of performance appraisal.

\subsection{Statement of the Problem}

The government of Kenya has made efforts in implementing public service reforms initiatives aimed at improving the performance of public servants in service delivery. The introduction of the new PAS; GOK, (2006), is yet another attempt by the GOK to manage and improve performance of civil service by enabling a higher level of staff participation and involvement of planning, delivery and evaluation of work performance. Performance Appraisal provides a good opportunity to formally recognize employee achievements and contributions to the organization and to ensure that a clear link is established and maintained between performance and reward. However, research has shown that these reforms have not achieved the envisaged results (Opiyo, 2006).

In the Ministry of Education, State Department of Early Learning and Basic Education (MoE), which comprises Nairobi City County, PA is viewed by many as a bureaucratic process which has little relevance to improving performance and accountability GoK (2012). A task force report that sought to align the activities of the Education sector in Kenya to the Kenya Constitution of 2010, further observed that the PA forms in MoE are filled as a matter of routine and not used as a means for enhancing staff development objective GOK, (2012). Perceptions of employees on the PAS affect the effectiveness of the system. Extreme dissatisfaction towards PAS by employees can lead to the failure of the system. Performance appraisals should help in determining how every employee fit into the organizational development and efficiency in performing all the assigned tasks and responsibilities. This study sought to understand the significance of employee attitude in the implementation of PAS.

Performance appraisal is a process for tracking contribution of individual work performance against organizational goals. Performance appraisal aims at enhancing public service efficiency and productivity in service delivery. It is implemented in the Ministry of Education as one of the requirements of all government ministries and agencies in Kenya. According to Fisher et al., (1996), insufficiency and/or inaccuracy in performance appraisal cause problems in two overarching goals of performance appraisals; To encourage high levels of employee motivation and to provide accurate information to be used in managerial decision making.

The government of Kenya has in the past made effort in launching and implementing Public Service Reform initiatives aimed at improving the performance of public servants in service delivery. However, these reforms have not achieved the envisaged results. In the Ministry of Education, reports reveal that staff view PA as a bureaucratic process, which has little relevance on improving performance and accountability. Further, the appraisal forms are not viewed as means for enhancing staff development objectives, instead they are filled as a matter of routine. There is evidence of room for improvement in the process and a lack of knowledge on the effect of employee attitude towards the implementation of 
PAS in the Ministry of Education, a gap this study intends to fill Researchers' observation, (2019). The related research on PA in Kenya focused on the effects of PA on service delivery, perceptions of employees on PAS and the effectiveness of PAS on performance in the public service and other organizations.

\section{Objectives of the Study}

This study pursued the following objectives:

- To examine the effect of employee attitude on the implementation of performance appraisal system in Kenya Ministry of Education

- To examine the Employees' Attitudes towards Performance Appraisal System in Kenya Ministry of Education

- To determine the relationship between the employee attitude and the implementation of performance appraisal in Kenya Ministry of Education

The findings of the study are expected to form a basis for the management of public service to carry out continuous monitoring of the performance appraisal in all government ministries and other institutions. The findings will also be useful to universities, research institutions and practitioners in enhancing teaching, theories and practice of performance appraisal systems. The knowledge excavation by this study is a great benefit to future researchers, as it serves as their point of reference, while the gaps not addressed by this study will provide a ground for future research. The findings will also be availed to the Ministry of Education for future implementation.

\section{Research Methodology}

The study adopted the Concurrent Mixed Method Design. This design focuses on collecting, analysing, and mixing both quantitative and qualitative data in a single study or series of studies. In this study, the two types of data were collected independently and the final inferences are based on both data analysis results in a research process as advised by (Creswell, 2014).

Concurrent mixed methods design was adopted in this study because of its advantages over other mixed methods. The design was preferred since its central premise is that the use of quantitative and qualitative approaches, in combination, provides a better understanding of research problems than either approach alone (Creswell, 2011).

The adoption of this design allowed the researcher to collect a variety of data on the effect of employee attitude towards implementation of performance appraisal system in Nairobi city County of Quantitative data answered the questions how and why the various variables of the employees affect their perception on the contribution of the performance appraisal system on the growth and development of their careers. In the quantitative approach, the study used the cross-sectional survey to examine the characteristics of employees' demographic characteristics on the contribution of the performance appraisal system on the growth and development of their careers in the Ministry of Education in Nairobi City County.

The qualitative data focused on investigating the effects of the employee attitude on implementation of the performance appraisal system from the County and sub county directors of education and the heads of directorates who are the supervisory staff in Nairobi City County and at the national headquarters. Interview guide was used to gather indepth information and focused exploration on individual perceptions and feelings of the supervisory staff.

The study was carried in Nairobi City County, which encompasses Kenya's capital city since it has the largest number of Ministry of Education employees compared to other counties. The study targeted the supervisory and non-supervisory employees of the Ministry of Education's State Department of Early Learning and Basic Education National office located in Jogoo House B, Nairobi City County office located in Nyayo House and Sub County offices located in the various sub counties in the county.

The targeted population for this study consisted of 255 officials of the State Department of Early Learning and Basic Education staff deployed within Nairobi City County. Eleven of the staff were in the supervisory level while the rest, 244, were non-supervisors. The researcher used both the probability and non-probability sampling methods. From the probability sampling methods, the researcher used a combination of stratified and simple random sampling. Purposive sampling, an aspect of a non-probability sampling, was used to pick all the 11 supervisory staff both at the National, County and Sub County offices. Supervisors were selected, using purposive sampling method due to their knowledge on the study topic and the role they play as supervisors in staff appraisal. According to Ilkeret. al(2016), the idea behind purposive involves identification and selection of individuals or groups of individuals that are proficient and well informed with a phenomenon of interest. Supervisory staff included heads of directorates, county director of education and subcounty directors of education. Non-supervisory staff consisted of technicians, clerks, secretaries, messengers and cleaners.

Since there were two categories of education professionals: general education officers and quality assurance officers, the study initially employed stratified sampling method. The staffs were stratified into two categories of Education officers and Quality Assurance officers. Stratifying was suitable in the selection of the education professional staff so as to give each one of them, as members of the population in the stratum, equal chances of being selected (Levy \&Lemeshow, 2013). Simple random sampling was then used within each stratum to select a total of 186 staff who participated in the study. The employees who were involved in the study were professionals in education deployed in the State Department of Early Learning and Basic Education. According to Human Resource Payroll Database (2019), the Ministry of Education has deployed a total number of 244 nonsupervisory and 11 supervisory staff in Nairobi City County and the Ministry of Education headquarters. Using these sampling methods, respondents from the non-supervisory staff and supervisory staff interviewees were selected to participate in this study.

The study used questionnaires to collect data from the sample of non-supervisory staff respondents, whereas, interview guide was used to collect data from the supervisory staff. 


\section{Research Findings and Discussions}

\subsection{Effect of Employee Attitude on the Implementation of Performance Appraisal System in Kenya Ministry of Education}

In this study, data was collected from of supervisory and non-supervisory staff of the Nairobi City County Education offices and the Ministry of Education headquarters. The return rate of questionnaires was excellent at $86 \%$, while participation in interviews was $100 \%$.

\subsubsection{Opinions on the Effect of Employee Attitude on Implementation of PAS}

Objective $\mathrm{x}$ was investigated ... It was found that... According to Boswell and Boudreau, (2000), a worker attitude towards PA is directly linked to job satisfaction; a worker who is satisfied with their job performs better and excels at what he does. It is therefore imperative for an organization to understand the attitude of its workers and measure the job satisfaction of its employees, as job satisfaction is essential for productivity, Table 1presents the analysis.

\begin{tabular}{|c|c|c|c|}
\hline \multicolumn{2}{|c|}{} & Frequency (f) & Percent (\%) \\
\hline \multirow{2}{*}{$\begin{array}{c}\text { Does attitude } \\
\text { affect PA? }\end{array}$} & Yes & 111 & 60.7 \\
\cline { 2 - 4 } & No & 72 & 39.3 \\
\cline { 2 - 4 } & Total & 183 & 100.0 \\
\hline
\end{tabular}

Table 1: Employee Attitude Effect on Implementation of PAS

Source: Field Data, 2019

The analysis in Table 1 indicates that a high percentage of employees (60.7\%) maintained that employees' attitudes affected the implementation of performance appraisal at the Ministry of Education. The finding implies that effective implementation of PAS at MoE is influenced by the nature of perceptions employees hold towards PAS. Therefore, as observed by Vasset, Marnburg, and Furunes (2011), applying a PAS method that is perceived as accurate and fair enhances the employee effectiveness, acceptance and employee motivation.Employee satisfaction with the PAS plays an essential role in its long-term efficiency. A negative reaction toward PAS can ruin it even if it was built meticulously. These study findings, also, allows us to assume that there is a strong link between the perception employees of the PAS, and their job satisfaction.The way these steps are executed determines the attitudes employees develop towards the overall performance appraisal system. For instance, if evaluation forms are developed with employee involvement or participation and awareness creation, then, this inspires in them a sense of ownership to the process and evokes positive attitudes from them. Similarly, creating rewards and sanction procedures with the consent of employees provokes a sense of responsibility and positive attitude towards the overall performance appraisal system Boswell \& Boudreau, (2000).The PA is seen as a key part of a strategic management approach, offering a tool that links employee skills and behaviours to the organization's strategic goals. To play this strategic role however, employees must perceive the program positively and be satisfied with its overall use. Brown, Hyatt, and Benson (2010) observed that the dissatisfaction and disagreement with the PA programme are linked to increasing work dissatisfaction, organizational commitment and the intention to resign.

\subsubsection{Rating Factors on Attitude of Employees on Implementation of Performance Appraisal}

The respondents were also asked to rate the factors on attitude of the employees towards performance appraisal system in the Ministry of Education. The basis of the analysis of the respondents' rating of factors promoting the implementation of the performance appraisal system in the Ministry of Education is the mean ratings computed from responses given by the selected respondents. This computation emanates from the values given by the respondent, where STRONGLY DISAGREE signifies value 1, DISAGREE signifies value 2, NOT SURE denotes value 3, AGREE denotes value four and STRONGLY AGREE, denotes value 5. Hence the maximum value is five, and the minimum value is 1 . The mid-point value is 3 , which represents the cut-off point, where any measure above three represents moderately high, high and very high. The mean ratings are thus interpreted in the same way. The mean ratings are then converted to percentage ratings, where the mid-point (cut-off point) is $60 \%$. Ratings above $60 \%$ is interpreted as high, where $60-74 \%$ is moderately high, $75-84$ is high, $85 \%$ and above is very high, and those below $60 \%$ is low and very low, successively. These findings on the employees, when asked to rate the factors on Attitude of Employees Towards Performance Appraisal, imply that the ratings of $60 \%$ and above is an indication of a positive attitude towards PAS at the MoE, while those below $60 \%$ imply a negative attitude. Table 2 presents this analysis.

\begin{tabular}{|c|c|c|c|}
\hline & Mean Rating & Percent Rating & Standard Deviation \\
\hline The system is simple to understand & 3.52 & 74 & 1.099 \\
\hline $\begin{array}{c}\text { The system is objective thus does not allow } \\
\text { subjectivity }\end{array}$ & 3.28 & 65.5 & 1.014 \\
\hline The performance appraisal system is important & 4.01 & 80.2 & 1.079 \\
\hline The system has been consistent over time & 3.04 & 60.8 & 1.181 \\
\hline $\begin{array}{c}\text { Employees are involved in developing performance } \\
\text { measures }\end{array}$ & 3.08 & 61.6 & 1.239 \\
\hline $\begin{array}{c}\text { The performance appraisal process is fair to all } \\
\text { employees }\end{array}$ & 3.08 & 61.6 & \\
\hline
\end{tabular}




\begin{tabular}{|c|c|c|c|}
\hline $\begin{array}{c}\text { Performance appraisal is not used to reward those } \\
\text { loyal to supervisors }\end{array}$ & Mean Rating & Percent Rating & Standard Deviation \\
\hline $\begin{array}{c}\text { The system is well structured and has relevant } \\
\text { content }\end{array}$ & 3.37 & 67.4 & 1.224 \\
\hline $\begin{array}{c}\text { The system does not need overhaul } \\
\text { The system has no loopholes for subjective } \\
\text { evaluation }\end{array}$ & 2.96 & 67.6 & 1.110 \\
\hline Overall Mean & 3.25 & 54.6 & 1.244 \\
\hline
\end{tabular}

Table 2: Employees' Attitudes towards Performance Appraisal System

$$
n=183
$$

Source: Field data, 2019

The findings of the analysis provide an overall rating of employees' attitudes towards performance appraisal at the MoE as moderately high, standing at $65.25 \%$.This rating by the respondents mean that employees' attitudes towards performance appraisal in the organization are moderately positive. This positive rating is primarily attributable to the employees' view that Performance appraisal system is important as indicated by the highest rating at $80.2 \%$. The attachment of importance is that performance appraisal of the employees is an extremely useful tool in the decisionmaking process of the organization in selection, training, promotion, pay increment, and in transfer. PAS should encourage employee development and stimulate their work motivation. According to Sabir, (2017), performance appraisal and review is the formal and systematic assessment of how well employees are performing their jobs in relation to established standards and the communication of that assessment to employees.

The respondents' viewed the system as simple to understand as they rated it at 74\%. This indicated that the employees were clear in their minds on their role and expectations on PAS. The fact that they understood the PAS made it easy for them to be positive and supportive towards its implementation and attach importance to it.

The results also showed that the employees had a view that performance appraisal was objective as the observed that it was not used to reward those loyal to supervisor (67.4\%). They also viewed the PAS as well-structured and with relevant content, rating it at $67 \%$. The foregoing findings are a testimony to the observation that the attitude of employees towards performance appraisal at MoE is a positive one from their understanding that the appraisal is designed to support and improve employee development and eliminate performance barriers. They therefore cannot deem the system efficient if they do not see the use of it and its fair and equitable nature Keeping \& Levy, (2020). The positive attitude, as reflected in the findings, is in regard to its significance, objectivity, and relevance of the PAS to the employees and MoE.

The concern of this study, however, is the $40.8 \%$ of the employees commented that there was need to overhaul the system, and $45.4 \%$ indicating that the system had loopholes for subjective evaluation. This result implies that there was a negative perception towards PAS by some MoE staff. This further suggests that a sizable number of staff lack confidence in the PAS in its current status and that it has potential to be subjective and this attitude could affect their willingness to participate or commitment to its feedback. However, it is important to observe that the quality of relationships between the employees and their supervisors can help to reinforce the perception they have of the PAS. Since the appraisal is conducted by the appraiser (supervisor), a positive relationship between the employee and the supervisor reinforces acceptance of the PAS process Elicker et al., (2006). Nye \& Witt (1993) in Khan, (2013) agrees that employees' perception of an unhealthy work atmosphere, such as an inequitable PA, can cause a negative attitude. In this regard, employees' perception of the way in which the PA system was implemented is significant in their perception of PA. On the basis of the foregoing analysis this study concluded that the management process of appraisal exercise at the MoE, should be taken with due consideration by both the appraises and appraisers. This is to enable them to have ample preparations, adequate knowledge, confidence and trust in appraisal system, which result into effective appraisal. Implementation of staff performance appraisals should be done on the basis of trust, and is not only a duty of the appraisers but also of the appraises to actively get involved in the exercise as it leads to the smooth running and provision of constructive feedback aimed at improvement of the performance. Nuwagaba (2015) explains that communication to appraisers and appraises before commencement of the appraisal exercise is a prerequisite to effective implementation of any staff performance appraisals. The employees should therefore be given prior communications so as to prepare them for effective exercise and enhancement of constructive improvements in employee performance.

\subsection{Employees' Attitudes towards Performance Appraisal System in Kenya Ministry of Education}

During the interview, employees were asked to give their personal views on how their attitudes affect implementation of performance appraisal system in the Ministry of Education. In terms of attitudes, some employees concurred that, the level of motivation they experience in the organization influenced their attitudes towards the appraisal system, as an interviewee expressed the following:

"when an employee is not motivated, the performance is low, motivation in terms of environment, recognition and enumeration is low. At times the employee has a negative attitude towards performance appraisal hence seeing it as an unnecessary evil that is there to waste their time"

Another respondent indicated that:

"Employees lack of motivation affects the implementation of PAS. Employee must view it worthwhile to give accurate information. Therefore, a positive attitude allows adoption of the system while negative attitude provokes dismissal of the system among the staff" 
These sentiments are pointers to the negative attitudes most employees harbour against performance appraisal at the MoE. As long as the equity perception of the performance appraisal is not high, their results tend to be ineffective and unusable as well for the employees, and can cause undesired results instead of effectiveness. Instead, application of a PAS that is perceived as accurate and fair enhances their effectiveness and acceptance among employees Turgutet al., (2014). Equity theory implies that if the employees believe their performance is accurately evaluated, they will be motivated to perform more highly.

Further, the employees' response indicated their dissatisfaction in terms of the nature of feedback given and time that is taken to fill up the PA forms when expressing their attitude towards performance appraisal system at MoE involved. The feedback the employees get for their appraisal is very important to them for their self-confidence and enthusiasm. In MoE, feedback is to be used as an evaluation to help determine rewards and to detect training needs and career enhancement opportunities. The nature of feedback given to the employees can affect their attitude towards the level and extent of their consumption of the feedback. If employees sense unfairness in the feedback, they are less likely to use the feedback from the appraisal to improve their performance. It also creates negative perception toward the PAS. The driving force should be that quality feedback improves performance (Dusterhoffet al., 2014).

As one staff points out:

"The right attitude (positive) synergizes intrinsic motivation. The attitude of an employee affects implementation of performance appraisal in that way, either positively or negatively"

Additionally, the time that is taken to fill up the PA forms effect the perception of the employees towards PAS. When employees, especially managers, view it as an administrative chore, it automatically leads them to devoting less time and attention to these processes which in turn will lead to disagreements with subordinates and negative results in the organizational performance Dusterhoffet al., (2014). Abdelhadi (2014), argues that the PA takes up a lot of time and energy and can create frustration that can undermine the teamwork and climate of trust.

However, some employees view performance appraisal positively, because they associate it with performance improvement initiatives. One employee explained that:

"If one is positive about the appraisal, they work and serve clients knowing it is their job to do so and do so happily. If one's attitude is negative, implementation of the process will be hampered and therefore no growth in performance achievements"

Employees gave various suggestions concerning strategies that can be used to positively enhance the function of the performance appraisal system at the MoE. The suggestions included the use of rewards where an employee has recorded excellent performance such as promoting employees based on performance carrying out sensitization on the importance of evaluation and use of PAS and involvement of employees in decision making concerning the design of the PAS, setting of targets and schedules for evaluation interviews. For instance, some respondents had this to say:

"Adhere to good HR management targets that is, training and capacity building promotion communication equitability mapping of all employees. An employee attitude towards implementation of performance appraisal can be positively enhanced by involving the employee in decision making"

Another employee stated that:

"An officer is given a chance to explain what he feels he can do and what resources are required. More importantly, let it be used to reward not just papers. Appraisals should be tied to actual work done, not just filling paper work"

In terms of promotions and performance targets, some supervisory staff expressed their views as follows:

"Before you are shortlisted for interview for promotion your performance has to be viable for review to determine if you have been meeting the departmental targets. Enables ministry identify responsible and performance productive personnel for career"

According to the supervisors interviewed, some employees view PAS as a venture that enhances one's work ethics and focused result outputs within time lines and set targets. It promotes continual performance progress and guides ontime management and supervision on how employees are working and meeting their targets in best way possible.

Other supervisors gave their views on PAS's contribution to career development and growth as follows:

"(PA) has enabled me shape up my knowledge and also it has enabled me to meet different people of various sectors in conferences and also exchanged opinions in various Ministries."

These views by employees indicate that they need a PAS which is collaborative and where feedback is genuinely used to plan improvements, training and rewards. These and other initiatives are likely to place the PAS system as a function that plays a valuable role in the organization and is respected by employees as a tool that improves their growth and development opportunities.

In exploring some views expressed by employees regarding reward for excellent performance; it can be argued that performance appraisal and reward system gives recognition or rewards to employees whose work advances organizational goals. That is what makes the system different from regular raises or merit pay. Picincu (2020) explains that annual raises help employees stay ahead of inflation. They are often combined with merit increases for good performance, but the difference in pay between average and superior employees is usually not large. Raises are an incentive to keep doing good work but not to do exceptional work.

Supervisor's views concerning sensitization of employees about importance of performance evaluation and use, adds to the general view of benefits of the Performance Appraisal. Omboi\&Kamencu, (2011) reason that, from the beginning and through the career, employees need to know how good they are in terms of particular fields of activity. It is difficult to give themselves an objective evaluation. Performance appraisal system is a useful management tool which helps to gain feedback, review and estimate whether the performance is effective and discuss what needs to be done for it to become so. Managers perform evaluations to benefit both employees and the employer. The most significant benefit of 
the appraisal system for the manager or the head of department is that it provides a document of employee performance over a specific period.

It can be argued that self-development is the most important benefit for the employee. Performance appraisal allows an employee to provide positive feedback as well as identify areas for improvement. An employee can discuss and even create a developmental (training) plan with the manager for improvement of skills. It motivates employees if supported by a good merit-based compensation system. Best performers get better pay and benefits packages. Similarly, those employees that lag behind get penalized.

The PAS should provide a structured process for an employee to approach the management for discussions, identify problems, clarify expectations, and plan for the future. It lets both manager and employee set up long-term and short-term goals (www.kpi.com/blog/2016/01/18/10-benefits-of-the-performance-appraisal-system).

Other employees of MoE stated that performance appraisal results are used in promoting employees based on performance. Kumar et al. (2012) argue most of the companies have yearly performance appraisal process for their employees. This process involves rating of employees by their manager. Organizations rely purely on manager's state of thinking and perception. Humans have tendency to become biased, corrupt, or give favour to some employees whom they like. This favour is due to some other reasons such as personal reason, social reason, political reason, or flattering. All these reasons are not related to the work that the employee is doing for the organization. Cawley et al, (1998) explains that the growth of an organization is based on the work the employees do. Growth is not achieved by keeping and encouraging non-performers MoE should instead encourage the performers. This will increase the efficiency of the employee, the process and MoE as an organization.

Some of the supervisory staff interviewed concurred that involving employees in decision-making concerning the design of the PAS contributes to their growth and development. In a meta-analysis of 27 studies containing 32 individual samples, Cawleyet al. (1998) explored the relationship between participation in the performance appraisal process and various employees. The findings confirmed that indeed, there is correlation between employee participation in decisionmaking concerning the design of the PAS and their performance as well as growth and development. This concurs with what a respondent expressed in the following assertion;

"It has enabled me to go up in the next level job group. It has enabled me to improve on my weak areas after discussing my performance with the supervisor."

Responses from supervisory staff further indicated that, involving employees in setting targets in the PAS contributes to employee performance, growth and development. Based on a study conducted by Baudler, C. (2011).in a large corporation, performance management can be used to increase levels of employee engagement. The researchers defined engaged employees as those who feel involved, committed, passionate, and empowered, and demonstrate those feelings in work behaviour. They discussed an expanded view of performance management, conceptualizing it as five major activities that serve to organize relevant behaviours shown to be either direct or indirect predictors of employee engagement in the study at the targeted corporation. These major activities include setting performance and development goals, providing on-going feedback and recognition, managing employee development, conducting mid-year and year-end appraisals, and building a climate of trust and empowerment. The researchers then examined how each of these major activities contributed to employee engagement. The results showed that, involving employees in setting targets in the PAS contributes to employee performance, growth and development.

\subsection{The Relationship of Employee Attitude and the Implementation Performance Appraisal in Kenya Ministry of Education}

The researcher sought to establish the relationship between employee attitude, as represented by the employee perception on feedback, interpersonal relationship between the appraiser and the appraisee, appraisal training, perception on organisational support and the implementation of performance appraisal system.

\subsubsection{Pearson Correlation on Employee Attitude and PAS Implementation}

The results of the Pearson correlation analysis of relationships between the attitude (independent variables) and the implementation of PAS (dependent variable) is shown on Table 3.

\begin{tabular}{|c|c|c|c|}
\hline \multicolumn{4}{|c|}{ Pearson Correlation } \\
\hline $\begin{array}{c}\text { Implementation of Performance } \\
\text { Appraisal System (Dependent Variable) }\end{array}$ & $\begin{array}{c}\text { Coefficient of } \\
\text { Correlation }\end{array}$ & Sig. (1-tailed) & $\mathrm{N}$ \\
\hline $\begin{array}{c}\text { Feedback management by MoE } \\
\begin{array}{c}\text { Interpersonal relationship between } \\
\text { appraiser and appraise }\end{array}\end{array}$ & .533 & .000 & 175 \\
\hline Appraisal training by MoE & .560 & .000 & 175 \\
\hline Perceived organization support by MoE & .639 & .000 & 175 \\
\hline
\end{tabular}

Table 3: Relationship between Employee Attitude and PAS Implementation

Source: Field data, 2019

This analysis indicates that there is a positive correlation between the factors that contribute to employee attitude and implementation of performance appraisal system. This implies that variations in Feedback management by MoE isassociated with variations in Implementation of Performance Appraisal System at 53.3\%, when other factors are held constant. It also implies that an improvement in appraisal feedback, the nature and how it is delivered is related to the implementation of PAS. In MoE, it has a positive change in Implementation of Performance Appraisal System. It further 
implies that deterioration in feedback management by MoE is related to negative change in Implementation of Performance Appraisal System. It is generally agreed that effective management of feedback in PAS motivates employees to improve their job performance by enhancing ability, encouraging effort, and acknowledging results. If included in a managerial strategy and given consistently, effective feedback management at MoE can reduce employee mistakes, enhance performance and increase efficiency within the workplace, thus improving their attitudes toward performance appraisal system.

The study found that, if MoE purposes to effectively manage the factors that influence the attitude of the employees, it will most likely lead to greater commitment from the employee to PA implementation, which can be viewed such as "psychological contract". It is the reciprocal attitudes and behaviours of the employees based on their perception to the effort of MoE in improving their skills, competencies and providing them future development opportunities as espoused by Jehanzeb, Rasheed, and Rasheed (2013) and Dockel, Basson, and Coetzee (2006). It can be argued that, from the findings of this study, employees of MoE tend to perceive that the governing body establishes an investment in their training as a sign of improvement in performance on their division based on human capital theory Scheible\&Bastos, (2013); Maurer \&Rafuse, (2001). It is thus, incumbent upon the management of MoE to strategize on PA training with a view to re-aligning employee commitment towards PA implementation.

The worker's perception of how an organization values him/her may be vital for determining his/her attitudes benefiting the organization. Additionally, it is suggested that the perceptions on organizational support are important to employees' perceptions of the quality of their exchange relationships with their organizations. It also indirectly influences employees' work attitudes and behaviours. At the same time, it is suggested that supervisors should take their time to discover the organizational resources at MoE that add value to the quality of exchange relationships between MoE and its employees and take measures to provide such resources where possible.

\section{Conclusion}

This study suggests the possibility that commitment shown by MoE towards employee through investment of PAS practices, especially in appraisal training and perceived organization support allows employees to correspond by being more committed towards performance appraisal and the organization, in general. In other words, when employees are provided with better performance appraisal system and training and development, it will lead to higher organizational commitment to PA implementation.

This high commitment would help employees to feel valued in the organization. The results derived from the analysis also indicated that performance appraisal factors contribute highly to organization productivity. It means that $50.1 \%$ of commitment depends on a performance appraisal system. One of the implications for supervisors in this context of conducting performance appraisal and training and organization support programmes are that the supervisors should stay attentive to the fact that only those employees who perceive these PAS practices as fair and beneficial would tend to commit and, in turn, have positive attitude towards MoE. This supports the study of Abdullah et al. (2011) in (Kadiresanet al., 2015) where it is proven that performance appraisal motivates and contributes to commitment of an employee.

Further, it suggests that the PA practices at the MoE should not only enhance the productivity and performance of the employees Kuvaas, (2006) in Liu et al., (2020) but well-designed PA system may also gain commitment of the employees and may positively affect their attitudes and behaviour. It is further supported empirically that there is a significant relationship effect between PA practices and organizational commitment and employee attitudes. The implications involve significant impact for $\mathrm{MoE}$ in attaining competitive advantage. Organizational commitment and employees' attitudes towards PA system may result in detrimental repercussions on the organizations due to Performance Appraisal and Training and Development. In a nutshell, implementation of effective PA system is imperative for both employee and organization which can lead to better productivity and performance.

\section{References}

i. Abdelhadi, N., Mansour J. B. \& André Leclerc, A. (2017). Performance Appraisal System and Employee Satisfaction: The role of trust towards supervisors" Journal of Human Resources Management and Labor Studies Vol. 3, No. 1, pp. 40-53.

ii. Baudler, C. (2011). Employee Engagement: Through Effective Performance Management by Edward M. Mone and Manuel London. Personnel Psychology.

iii. Boswell, W. R., \& Boudreau, J. W. (2000). Employee satisfaction with performance appraisals and appraisers: The role of perceived appraisal use. Human Resource Development Quarterly, 11(3), 283-299.

iv. Bowling, N. A., Beehr, T. A., Wagner, S. H., \&Libkuman, T. M. (2005). Adaptation-Level Theory, Opponent Process Theory, and Dispositions: An Integrated Approach to the Stability of Job Satisfaction. Journal of Applied Psychology, 90(6), 1044-1053.

v. Brewster, C., \&Suutari, V. (2005). Guest editorial. Global HRM: aspects of a research agenda. Personnel Review.

vi. Brown, M., Hyatt, D. \& Benson, J. (2010). Consequences of the performance appraisal experience. Personnel Review. 39. 375-396. 10.1108/00483481011030557.

vii. Cawley, B. D., Keeping, L. M., \& Levy, P. E. (1998). Participation in the performance appraisal process and employee reactions: A meta-analytic review of field investigations. Journal of Applied Psychology, 83(4), 615633. https://doi.org/10.1037/0021-9010.83.4.615.

viii. Creswell, J. W. (2014). Research Design: Qualitative, Quantitative and Mixed Methods Approaches (4th ed.). London: Sage Publications Ltd. 
ix. Creswell, J. W., \& Plano Clark, V. L. (2011). Designing and conducting mixed methods research (2nd ed.). Thousand Oaks, CA: Sage Publications, Inc.

x. Döckel, A, Basson, JS \& Coetzee, M. (2006). The effect of retention factors on organizational commitment: An investigation of high technology employees - Journal of Human Resource Management - journals.co.za.

xi. Dusterhoff, C. \& Cunningham, J. and MacGregor, J. (2014). The Effects of Performance Rating, Leader-Member Exchange, Perceived Utility, and Organizational Justice on Performance Appraisal Satisfaction: Applying a Moral Judgment Perspective. Journal of Business Ethics, 2014, vol. 119, issue 2, 265-273.

xii. Elicker, J. D., Levy, P. E., \& Hall, R. J. (2006). The role of leader-member exchange in the performance appraisal process, Journal of Management, 32, 531-551.

xiii. Fletcher, C (2004). Appraisal and Feedback, Making Performance Review Work. London: Chartered Institute of Personnel and Development.

xiv. GOK (2006). "Results for Kenyans: Capacity Building Programme for Transforming the Public Service," Public Service Reform and Development Secretariat, December, 2006.

xv. GOK (2008). Rapid Results Initiative: Public Sector Reforms \& Performance Contracting, Kenya. Nairobi: Government Printer.

xvi. GOK (2012). Government of Kenya Gazette Notices. Nairobi: Government Printer.

xvii. GOK (2016). Guidelines on Deepening Rationalization, Nairobi: Government Printer

xviii. GOK (2019). Human Resource Payroll Database Nairobi: Ministry of Education

xix. Gold, J., \& Bratton, J. (2003). The Dynamics of Professionalization: Whither the HRM Profession. In Critical Management Studies Conference (Vol. 2, No. 3, pp. 17-22).

xx. Griffin R. W, \& Moorhead G. (2014), Organizational Behavior Managing People and Organizations Ninth Edition. Texas A\&M University and Arizona State University.

xxi. Ilker E, Sulaiman A.M., Rukayya S, A. (2016). Comparison of Convenience Sampling and Purposive Sampling. American Journal of Theoretical and Applied Statistics. Vol. 5, No. 1, 2016, pp. 1-4. doi: 10.11648/j.ajtas.20160501.11.

xxii. Jehanzeb, K. and Beshir, N.A. (2013). Training and Development Program and Its Benefits to Employee Organization: A Conceptual Study. European Journal of Business and Management, 5, 243-252.

xxiii. Jehanzeb, K., Rasheed, A. \& Rasheed, M. F. (2013). Organizational commitment and turnover intentions: impact of employee's training in private setor of Saudi Arabia. International Journal of Business and Management, Vol. 8, No. 8, pp. 79-90.

xxiv. Johns, G. (2010). Presenteeism in the workplace: Montreal: John Wiley \& Sons, Ltd.

xxv. Kadiresan, V. \&Selamat, M. \&Selladurai, S.\&Ramendran, C. \&Moona H. M., Ramesh, K. (2015). Performance Appraisal and Training and Development of Human Resource Management Practices (HRM) on Organizational Commitment and Turnover Intention. Asian Social Science.

xxvi. Keeping, L., \& Levy, P. E. (2020). Performance appraisal reactions: Measurement, modelling, and method bias. Journal of Applied Psychology, 85(5), 708-723.

xxvii. Khan, M. F. U. (2013). Role of Performance Appraisal System on Employees Motivation. IOSR Journal of Business and Management, 8(4), 66-83.

xxviii. Kuvaas, B. (2006). Work Performance, Affective Commitment, and Work Motivation: The Roles of Pay Administration and Pay Level. Journal of Organizational Behavior.

xxix. Levy, P. S., \&Lemeshow S. L. (2013). Sampling of Populations: Methods and Applications, E-bok (EPUB - DRM), Engelska.

xxx. Liu, Y. \& Zhu, N. \&Jianwei, Z. \& Raza, J. (2020). Does organizational reciprocity improve employees' motivation? The mediating role of basic psychological need satisfaction. Current Psychology.

xxxi. Maurer, T. \&Rafuse, N. (2001). Learning, Not Litigating: Managing Employee Development and Avoiding Claims of Age Discrimination. Academy of Management Executive.

xxxii. Nuwagaba, F. (2015). Factors Affecting the Implementation of the Performance Appraisal System in Rwanda: A Case of Nyamasheke District Local Government. Jomo Kenyatta University of Agriculture and Technology.

xxxiii. Nye, L. G., \& Witt, L. A. (1993). Dimensionality and construct validity of the Perceptions of organizational Politics Scale (POPS). Educational and Psychological Measurement, 53, 821-829.

xxxiv. Ochot, G. N., Maronga, E., Muathe, S., Nyabwanga, R. N., \&Ronoh, P. K. (2012). Factors Influencing Employee Performance Appraisal System: A Case of the Ministry of State for Provincial Administration \& Internal Security, Kenya. International Journal of Business and Social Science, 3(20), 37 - 46.

xxxv. Omboi, B. M., \&Kamencu, S. M. (2011). The Effect of Performance Appraisal Systems on Employees in Kenya Tea Development Agency: A Survey of Selected Tea Factories in Meru County-Kenya. Research Journal of Finance and Accounting, 2(3).

xxxvi. Opiyo, H. (2006). Civil Service Reform Policy in Kenya: A review of the Retrenchment Strategy: Journal of Applied Psychology. Vol. 77 pp.693-974.

xxxvii. Picincu, A., (2020). What Are the Benefits of Performance Appraisals to the Organization; Harvard Business Review: Why Managers Shouldn't Have the Final Say in Performance Reviews

xxxviii. Rao, V.S.P (2005). Human Resource Management: Text and Cases. (2nd ed.). New Delhi: Excel Books.

xxxix. Saari, L. M., \& Judge, T. A. (2004). Employee attitudes and job satisfaction. Human Resource Management, 43(4), 295-407. 
xl. Sabir, A. (2017). Performance Appraisal-A Documentation and Evaluation of Employees. American Journal of Management Science and Engineering. 2. 29. 10.11648/j.ajmse.20170202.12

xli. Scheible, A. \&Bastos, A. (2013). An Examination of Human Resource Management Practices' Influence on Organizational Commitment and Entrenchment. BAR - Brazilian Administration Review.

xlii. Segalla, M., \&DeNisi, A. (2014). Performance Appraisal, Performance Management, and Firm-Level Performance: A Review, a Proposed Model, and New Directions for Future Research. The Academy of Management Annals, 8(1), 127-179.

xliii. Shen, J. (2004). International Performance Appraisals: Policies, Practices and determinants in the case of Chinese multinational companies. International Journal of Manpower, Vol. 25 (6), pp 547 - 563

xliv. Swanepoel, B., Erasmus, B., Van, W. M. \& Schenk, H. (2000). South African Human Resource Management: Theory and Practice. Cape Town: Juta and Company.

xlv. Swanepoel, S., Mangonyane, N. B., \& Botha, P. a. (2014). Politicisation of performance appraisals. SA Journal of Human Resource Management, 12(1). doi:10.4102/sajhrm. v12i1.525.

xlvi. Turgut, H. \& Sani M. I., (2014). Evaluation of Performance Appraisal Methods through Appraisal Errors by Using Fuzzy VIKOR Method. Tourism Management, Baskent University, Ankara, Turkey.

xlvii. Vasset F, Marnburg E, \&Furunes T., (2011). The effects of performance appraisal in the Norwegian municipal health services: a case 